\section{DENTAL STUDENT ENTREPRENEUR WINS PRIZE}

A young entrepreneur based in Cardiff has scooped a national award after setting up his own company selling loupes to fellow dental students in an aim to improve their physical wellbeing.

Dave Stone aged 27, impressed the panel of judges in the Shell LiveWIRE Grand Ideas Awards with his idea and has been awarded £1,000 to develop UKloupes. UKloupes was set up to ena- ble students to buy high quality loupes at a fraction of their retail price.

As a final year dental student, Dave was determined for loupes to be made available to all oral healthcare students. Concerned about the high prices of loupes on the market, he looked into selling the device directly to his peers and found by cutting out the middle man, he could sell them at a more affordable price.

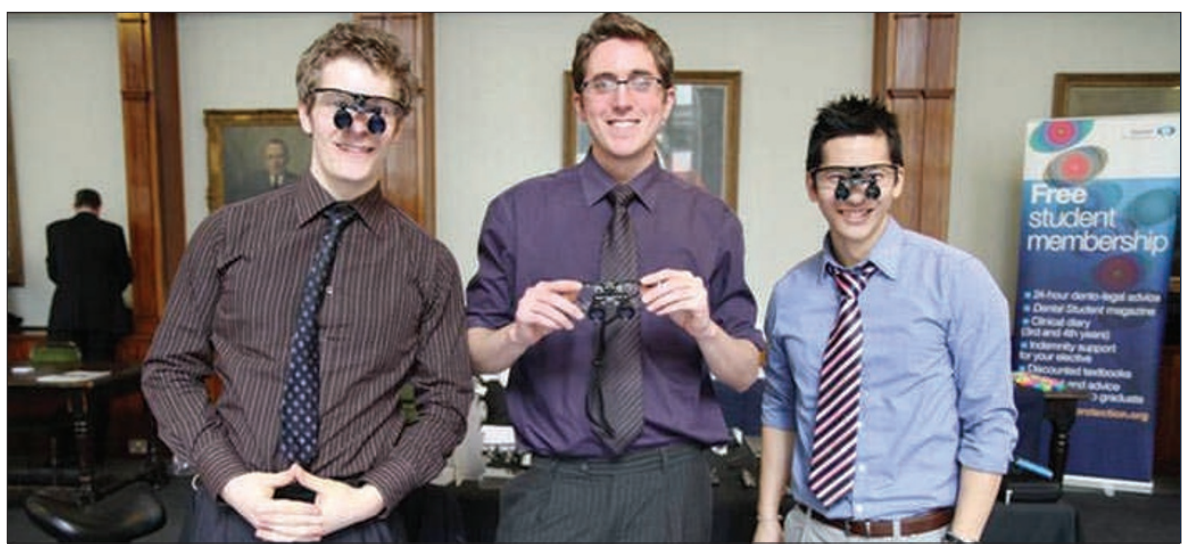

The Shell LiveWIRE Grand Idea Awards were launched in 2009 and are designed to give aspiring entrepreneurs a nostrings-attached financial boost of $£ 1,000$ to help them get their business ideas off the ground. The awards are held monthly and entrepreneurs from all over the UK can submit their entries through the LiveWIRE website.

Dave Stone commented, 'In such a tough economic climate, it's easy to be disheartened about setting up on your own, but for all the young entrepreneurs out there, I urge you to give it a go. Initiatives, like Shell LiveWIRE, are often key to turning your business ideas into a reality.'

Dave hopes to expand his business and help other dental students by training a representative at every dental school in the country to teach other students about the benefits of loupes and UKLoupes products. To find out more or enter the Shell LiveWIRE Grand Ideas Awards visit www.shell-livewire.org.

\section{GROUP LEADER APPOINTED}

King's Health Partners has recently appointed the next wave of clinical academic group leaders of the Academic Health Sciences Centre. Clinical academic groups (CAGs) are structures currently being introduced across King's Health Partners Academic Health Sciences Centre (AHSC) which will bring clinical services, research and education activities together within a series of single managerial units.

Professor Nairn Wilson has been appointed Leader of the Dental Clinical Academic Group. Professor Wilson is currently the Dean and Head of the King's College London Dental Institute at Guy's, St Thomas' and King's College Hospitals, and Deputy Vice Principal (Health) at King's College London.

King's Health Partners' Executive Director, Professor Robert Lechler, said: 'I am delighted that we have made further appointments to the positions of Clinical Academic Group Leader. The establishment of clinical academic groups is an extremely important step in formalising the infrastructure that is required to drive forward King's Health Partners and to realise our mission of becoming the UK's leading academic health sciences centre.'

\title{
RESEARCH PRIZE AWARDED FOR DIABETES WORK
}

Dr Maria Retzepi, Lecturer in Periodontology at the UCL Eastman Dental Institute, was awarded the André Schroeder Research Prize at the World Symposium of the International Team for Implantology (ITI) in Geneva, Switzerland recently.

Dr Retzepi was commended for her work on 'The effect of experimental diabetes on guided bone regeneration'. She investigated the impact of uncontrolled and controlled diabetes mellitus on the histological events and on the gene profiles expressed by cells involved in the healing process following guided bone regeneration.

Her work demonstrated that although diabetes compromises the initial stages of bone healing, guided bone regeneration can provide an environment that is conducive for significant, even though delayed, formation of new bone.

The use of insulin to control diabetes may enhance the bone regeneration potential. Understanding the genetic aspects of the metabolic status may lead to new approaches for treating oral bone defects in patients with diabetes mellitus.

In addition to Dr Retzepi, the other authors/collaborators of the awarded project were Dr Ivan Wall (UCL Biochemical Engineering) and Professor Nikos Donos (UCL Eastman Dental Institute).

The work was part of Dr Retzepi's PhD project where Professor Donos was the primary supervisor and Professor Mark Lewis (formerly of the UCL Eastman Dental Institute) the secondary supervisor. The funding supporting the scientific work was derived from research grants secured by Professor Donos' team.

First presented in 1992, the André Schroeder Research Prize - which is worth CHF 20,000 - serves to promote new scientific findings in oral implantology and related fields. It is given in honour of the late Professor André Schroeder (1918-2004), who pioneered dental implantology and whose life's work contributed greatly to modern dentistry. 